\begin{tabular}{|c|c|}
\hline \hline & International Journal of Current Research in \\
Biosciences and Plant Biology & Volume $8 \cdot$ Number o5 (May-2021) • ISSN: 2349-8080 (Online) \\
\hline EXCELLENT \\
PUBLISHERS
\end{tabular}

Review Article

doi: $\underline{\text { https://doi.org/10.20546/ijcrbp.2021.805.002 }}$

\title{
Garcinia fruit: in the forests and domestic orchards, the prevention of diseases of modernity
}

\author{
Flavia Maria Vasques Farinazzi-Machado $\mathbb{D}^{1} *$ and André Ribeiro da Silva $\mathbb{i}^{2}$ \\ ${ }^{1}$ Faculty of Food Technology of Marilia (FATEC) Marilia/SP - Brazil \\ Castro Alves Avenue, 62, Marilia, São Paulo, Brazil - 17506-000 \\ ${ }^{2}$ State University of Londrina, Londrina, $P R-$ Brazil \\ Celso Garcia Cid Highway | PR 445 Km 380 | Brazil - 86.057-970
}

*Corresponding author; e-mail: farinazzimachado@ hotmail.com

\begin{tabular}{|c|c|}
\hline Article Info & Abstract \\
\hline $\begin{array}{l}\text { Keywords: } \\
\text { Anti-hyperglycemic } \\
\text { Anti-inflammatory } \\
\text { Antimutagenic } \\
\text { Antioxidants } \\
\text { Cardiovascular disease } \\
\text { Garcinia }\end{array}$ & $\begin{array}{l}\text { The genus Garcinia has many varieties of fruit trees, which are found in rural and urban backyards, } \\
\text { tropical forests and domestic orchards of several tropical countries. Fruits have a great diversity of } \\
\text { metabolites, among which phenolic compounds stand out for their potential antioxidant, anti- } \\
\text { inflammatory and other effects, and which have a preventive action on diseases of modernity. This } \\
\text { review aimed to associate studies on the metabolic activities of Garcinia fruits and their numerous } \\
\text { effects on health risk factors, such as obesity, hyperglycemia, inflammatory processes and } \\
\text { dyslipidemias. Scientific articles published in English, Portuguese and Spanish were selected, which } \\
\text { carried out studies involving the administration of Garcinia fruits in vitro and in vivo, mainly in the } \\
\text { last five years. Sixty relevant articles were included in the study. Studies have shown that the Garcinia } \\
\text { fruit species can be used in body weight control and prevention of cardiovascular disorders, cancer and } \\
\text { diabetes mellitus, among other diseases associated with oxidative stress. }\end{array}$ \\
\hline
\end{tabular}

- Received: 05 March 2021 • Revised: 24 April 2021 • Accepted: 30 April 2021 • Published Online: 6 May 2021

\section{Introduction}

Plants of the genus Garcinia L. (Family: Clusiaceae Lindl.) can be found in tropical Africa, Asian continent such as Thailand, Myanmar, Philippines, Sri Lanka, Indonesia, New Caledonia, Polynesia and tropical regions of Brazil. Garcinia plants are used as ornamentation, food preservative, oil extraction, wood and fresh fruits around the world. Because they are found in rainforest and small farms, considered rich reservoirs of biodiversity, some of them are widely used in many countries for the treatment of various diseases by popular medicine (Espirito Santo et al., 2020; Liu et al., 2016).

Many varieties of Garcinia species are fruit trees, e.g., Garcinia atroviridis Griff. ex T.Anderson, G. cochinchinensis (Lour.) Choisy, G. cowa Roxb. ex Choisy, G. dulcis (Roxb.) Kurz, G. forbesii King, G. gummi-gutta (L.) Roxb, G. livingstonei T.Anderson, 
G. madruno (Kunth) Hammel and G. mangostana L. (Fig. 1), distributed in urban and rural yards, as well as small domestic orchards. Among the fruit plants, the most well-known species are the mangosteen (G. mangostana) and G. gummi-gutta, also called $G$. cambogia (Hargunani et al., 2020; Semwal et al., 2015).

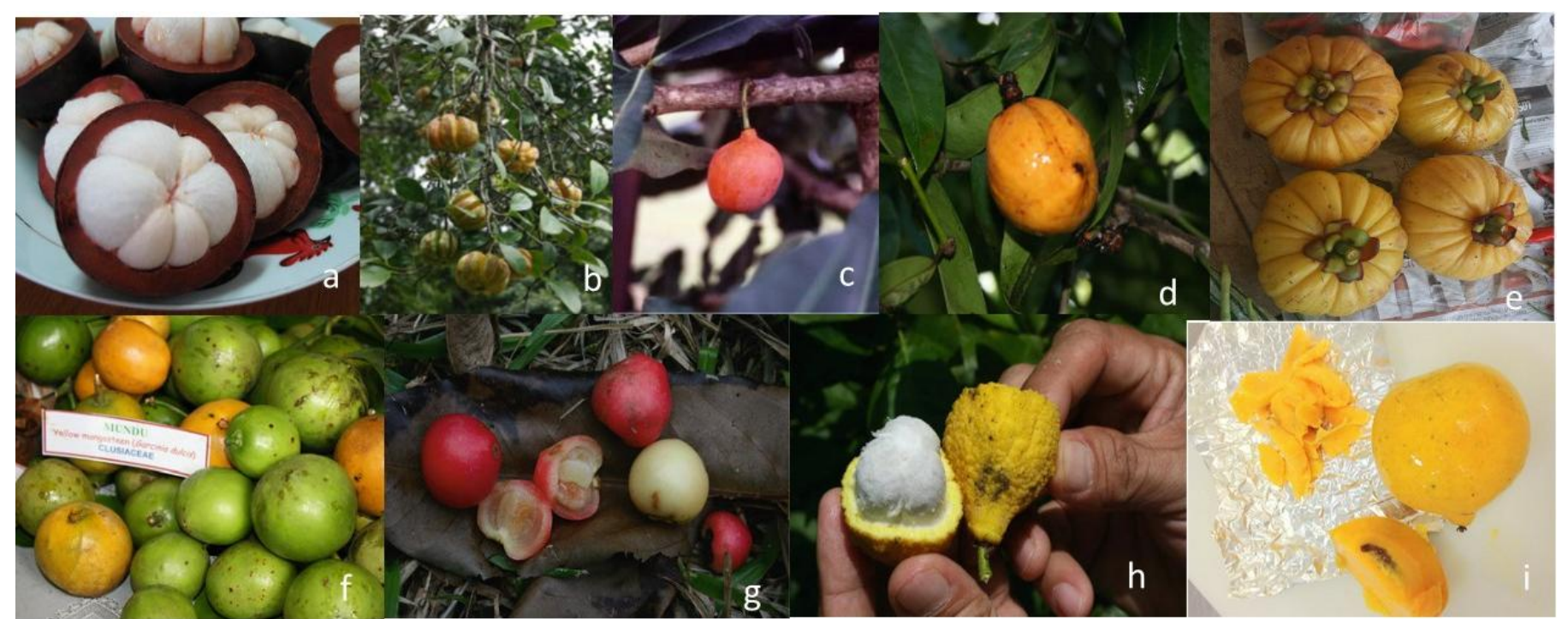

Fig. 1: Fruit varieties of Garcinia species: (a) Garcinia mangostana, (b) G. gummi-gutta (cambogia), (c) G. livingstonei, (d) G. cowa, (e) G. atroviridis, (f) G. dulcis, (g) G. forbesii, (h) G. madruno, (i) G. cochinchinensis.

This genus presents a remarkable diversity of oxidized and prenylated phenolic derivatives, including xanthones, flavonoids, phenolic acids, benzophenones and hydroxycitric acid, responsible for the potential effects observed by the consumption of these plants, such as the so-called diseases of modernity, e.g., obesity, type 2 diabetes mellitus, cancer and cardiovascular disorders (Espirito Santo et al., 2020; Liu et al., 2015).

The antioxidant potential, anti-inflammatory and antiobesity activities have been observed in extracts of several species of this genus, such as $G$. cola (Oyagbemi et al., 2016), G. cambogia (Hargunani et al., 2020), G. mangostana (Taher et al., 2016), G. indica (Panda et al., 2012), G. xanthochymus (Bheemaiah and Kushalappa, 2019), G. parvifolia (Hassan et al., 2017), G. pedunculata (Sarma et al., 2016), G. achachairu (Bagattoli et al., 2016), among others. This review aimed to present studies that have proven beneficial physiological and metabolic effects using the Garcinia fruit in vitro and in vivo.

\section{Materials and methods}

The Lilacs-Bireme, SciELO, Medline and Scholar Google databases were consulted. Scientific articles published in English, Portuguese and Spanish were selected, which carried out studies involving the administration of the Garcinia fruits in vitro and in vivo. Sixty relevant articles were included in the study.

The descriptors used for research articles in the databases were as follows: "Garcinia fruit", "antioxidant", "antimutagenic", "anti-inflammatory", "anti-hyperglycemic", "weight loss and obesity and anti-hyperlipidemic".

\section{Results and discussion}

Many studies have shown the beneficial physiological and metabolic effects of Garcinia species. Table 1 presents a summary of the species used, useful part, effects and mechanisms of action.

\section{Garcinia and weight control}

The significant increase in the prevalence of overweight and obesity in increasingly younger adults has aroused the concern of researchers and professionals, due to the damage and health problems caused by excess adiposities, such as diabetes, hyperlipidemia, hypertension, and cardiovascular diseases (Marques et al., 2018; Seidell and Halberstadt, 2015). 
Scientific evidence links weight and obesity control with adequate consumption of fruits and vegetables (Yazew and Daba, 2020). The World Health Organization says that the minimum daily intake of $400 \mathrm{~g}$ of fruits and vegetables is an important factor in preventing obesity and related chronic disorders (Ness, 2004).

Table 1. Beneficial physiological and metabolic effects of Garcinia species.

\begin{tabular}{|c|c|c|c|}
\hline Name scientific & Parts & Activities and effects & References \\
\hline \multirow[t]{3}{*}{ G. pedunculata } & Pulp & Weight reduction & Sarma et al. (2016) \\
\hline & & Antihyperglycemic and antioxidant effects & Ali et al. (2017) \\
\hline & & Decrease in triglycerides and LDL-c & Sarma et al. (2016) \\
\hline \multirow[t]{2}{*}{ G. brasiliensis } & Pulp & Reduction of adiposity and obesity & Moreira et al. (2017) \\
\hline & Pulp & Antioxidant activity & Infante (2013) \\
\hline \multirow[t]{6}{*}{ G. mangostana } & Pulp and leaves & Weight reduction & Watanabe et al. (2018) \\
\hline & & Anti-inflammatory capacity & Xie et al. (2015) \\
\hline & & Decrease inflammatory markers & Udani et al. (2009) \\
\hline & Pericarp & Hypoglycemic effect & Taher et al. (2016) \\
\hline & & Decrease in triglycerides and LDL-c & Abuzaid et al. (2017) \\
\hline & & Antitumor effect & $\begin{array}{l}\text { Mohamed et al. (2017); Ovalle- } \\
\text { Magallanes et al. (2017) }\end{array}$ \\
\hline \multirow[t]{4}{*}{ G. cambogia } & Pulp & $\begin{array}{l}\text { Decrease visceral adiposity, adipocyte size and } \\
\text { reduction body weight }\end{array}$ & $\begin{array}{l}\text { Kim et al. (2013) } \\
\text { Oluyemi et al. (2007) }\end{array}$ \\
\hline & & $\begin{array}{l}\text { Control plasma lipids and reduction oxidative } \\
\text { stress }\end{array}$ & Amin et al. (2011) \\
\hline & & Improvement in lipid profile & Sripradha et al. (2016); \\
\hline & & $\begin{array}{l}\text { Decrease levels plasma leptin and } \\
\text { proinflammatory cytokine }\end{array}$ & Sripradha and Magadi (2015) \\
\hline \multirow[t]{3}{*}{ G. indica } & Pulp & Hypoglycemic effect & Kirana and Srinivasan (2010) \\
\hline & & Antioxidants effects & Mishra et al. (2006) \\
\hline & Peels & Hepatoprotective activity & Panda et al. (2012) \\
\hline G. kola & Pulp & Hypoglycemic effect & Farahna et al. (2017) \\
\hline \multirow[t]{3}{*}{ G. atrovirids } & Pulp and leaves & Antihyperlipidemic activity & Al-Mansoub et al. (2017) \\
\hline & & Protection against atherosclerosis & Amran et al. (2009) \\
\hline & & Antioxidant activity & Nursakinah et al. (2012) \\
\hline G. brasiliensis & Pulp and peels & Antioxidant activity & Infante (2013); Naves (2014) \\
\hline \multirow[t]{2}{*}{ G. achachairu } & Pulp & $\begin{array}{l}\text { Antioxidant activity in the ABTS, DPPH and } \\
\text { FRAP assays }\end{array}$ & Virgolin (2015) \\
\hline & & Inhibition of cell tumor growth & Bagattoli et al. (2016) \\
\hline G. lanceifolia & Pericarp & $\begin{array}{l}\text { Antioxidant activity in the ABTS and DPPH } \\
\text { models }\end{array}$ & Gogoi et al. (2015) \\
\hline G. xanthochymus & Pericarp & $\begin{array}{l}\text { Antioxidant activity in the ABTS and DPPH } \\
\text { models }\end{array}$ & Gogoi et al. (2015) \\
\hline G. morella & Pulp & Anti-proliferative action & Choudhury et al. (2018) \\
\hline G. opaca & Pulp & Antitumor effect & Jabit et al. (2009) \\
\hline \multirow{2}{*}{ G. garderiana } & Pulp and leaves & Antiproliferative and antioxidant activity & Demenciano et al. (2020) \\
\hline & Pulp and peels & Hepatoprotective activity & $\begin{array}{l}\text { Abu Bakar et al. (2015); Gogoi et } \\
\text { al. (2017) }\end{array}$ \\
\hline
\end{tabular}

Consumption of some species of Garcinia has been associated with weight control and adiposity levels. The methanolic extract of the G. pedunculata pulp (200 mg $\mathrm{kg}^{-1}$ of body weight) was administered to obese rats 
induced by a high-fat diet, which caused a weight reduction of about $60 \%$ compared to the control group that received the same hypercaloric diet without fruit extract for 60 days (Sarma et al., 2016). Similarly, the ethanolic extract of $G$. brasiliensis reduced the indicators of adiposity and obesity (Lee Index) in animals treated with a high-fat diet after 8 weeks (Moreira et al., 2017). The use of G. mangostana extract for 26 weeks in obese adult women with insulin resistance promoted an improvement in body weight compared to the control group, but the values were not significant (Watanabe et al., 2018).

In a study by Farinazzi-Machado et al. (2016), the pulp juice of the yellow mangosteen ( $G$. cochinchinensis Choisy), a variety found in the orchard of a Brazilian college, significantly decreased visceral fat in experimental models after 40 days of treatment. Supplementation with $G$. cambogia also caused a significant decrease in visceral adiposity and adipocyte size by inhibiting the activity of fatty acid synthase and mRNA expression in the visceral adipose tissue of mice fed high-fat diets $(45 \mathrm{kcal} \%$ fat) for 16 weeks (Kim et al., 2013). The ethanolic extract of the same species administered to rats orally at doses of 200 and $400 \mathrm{mg}$ $\mathrm{kg}^{-1}$ per day, for 5 weeks, significantly reduced body weight, in the experimental by Oluyemi et al. (2007).

According to Fassina et al. (2015), several studies suggest positive results from the effectiveness of $G$. cambogia on the weight loss process, since the ideal dosage of consumption is not yet well established. Chuah et al. (2013) reported that a substantial amount of hydroxycitric acid, the main component responsible for the anti-obesity effect by reducing lipogenesis and accelerating fat oxidation, is present in the pericarp of the G. cambogia fruit.

\section{Garcinia and glycemic control}

Diabetes mellitus is a major global health concern that is expected to reach 642 million diabetics by 2040 (IDF, 2015). Despite innovative methods in the management of diabetes mellitus, morbidity and mortality remain high (Akshay Kumar et al., 2017). Studies have shown that several plant-derived natural products with different chemical structures can modulate blood glucose levels through various mechanisms and can be used to treat diabetes (Lee et al., 2018). Taher et al. (2016) described a 28-day administration to diabetic rats $(50,100$, and $200 \mathrm{mg} \mathrm{kg}^{-1}$ ) of an ethanolic extract from the
G. mangostana pericarp that exhibited a hypoglycemic effect. Similar doses of $G$. indica aqueous extract (100 $\mathrm{mg}$ and $200 \mathrm{mg} \mathrm{kg}^{-1}$ ) promoted a significant reduction in fasting and postprandial hyperglycemia in type 2 diabetic rats, with increased blood levels of erythrocyte glutathione (Kirana and Srinivasan, 2010).

Glutathione, the most abundant thiol that exists as a reduced and oxidized form in cells, plays an important role against oxidative stress. Its intracellular depletion leads to neurodegeneration, myocardial infarction and other cardiovascular complications in diabetes (Mohammedi et al., 2016).

In a study by Ali et al. (2017), streptozotocin-induced diabetic rats showed a significant improvement in hyperglycemia (42\%) and plasma insulin levels, and a decrease in glycated hemoglobin levels when treated with high doses $\left(1000 \mathrm{mg} \mathrm{kg}^{-1}\right)$ of $\mathrm{G}$. pedunculata methanolic extract. The aqueous extract of $G$. kola also administered to diabetic rats promoted an improvement in the glucose levels of these animals in relation to those that received distilled water, as demonstrated by Farahna et al. (2017).

\section{Cardiovascular protection}

Cardiovascular diseases are responsible for the highest mortality rate worldwide. In their multiple causes, while the main risk factors for these disorders, in addition to obesity, hypertension and smoking, dyslipidemias, which are characterized by increased serum levels of total and LDL cholesterol, and decreased of HDL cholesterol, are among the most significant factors (Guedes, 2016; Guerrero-García and Rubio-Guerra, 2018).

Although alternative mechanisms have been suggested, the simplest chain of events is that high concentrations of triglyceride are a marker for high cholesterol-rich remnants that, when entering into the intima, leads to low-grade inflammation, formation of foam cell, atherosclerotic plaques and, ultimately, cardiovascular disease and increased mortality (Nordestgaard and Varbo, 2014). Therefore, therapeutic actions resulting from the administration of plant extracts have caused a positive impact on plasma lipoproteins levels and, consequently, on the prevention of cardiovascular disorders in several studies (Calvo and Cavero, 2014; Farinazzi-Machado et al., 2017). 
Amin et al. (2011) observed that the application of 500 $\mathrm{mg}$ day $^{-1}$ of G. cambogia for 8 weeks in experimental models resulted in an improvement in plasma lipid levels and a reduction in oxidative stress. Also in experimental models, administration of $G$. cambogia ethanolic extract along with a high-fat diet significantly reduced total plasma cholesterol, triglycerides and nonHDL-C, in addition to increasing HDL-C levels (Sripradha et al., 2016). This species also caused a significant reduction in triglyceride levels in obese women who were treated daily $\left(2.4 \mathrm{~g} \mathrm{day}^{-1}\right)$ with the fruit extract for 60 days (Vasques et al., 2014).

The ethanolic extract of $G$. mangostana pericarp significantly decreased the level of triglycerides and LDL in rats after 9 weeks, at doses of $200 \mathrm{mg} \mathrm{kg}^{-1}$ and $500 \mathrm{mg} \mathrm{kg}^{-1}$ (Abuzaid et al., 2017).

Dehydrated pulp extracts of $G$. pedunculata caused a significant reduction in triglyceride (32\%) and LDL-C (38\%) values in the blood of male Wistar rats (Sarma et al., 2016).

Aqueous and methanolic extracts of $G$. atroviridis presented significant antihyperlipidemic activity in male rats treated for 16 weeks (Al-Mansoub et al., 2014). Working with the same fruit, Amran et al. (2009) showed that co-administration of the methanolic extract with a cholesterol-rich guinea pig diet reduced the serum lipid profile, as well as a reduction in fat deposition in the aorta, which may contribute to a lesser possibility of developing atherosclerosis.

\section{Anti- inflammatory activity}

Inflammation (derived from the Latin: inflammatio), also known as an inflammatory process, is a biological response of the body against an aggressive agent (González-Chávez et al., 2011). Obesity is one of the many chronic diseases that involve an inflammatory response characterized by an increase in cytokines and proteins of the acute inflammatory phase, e.g., Creactive protein (CRP) and fibrinogen (Veigas et al., 2012). Specifically, macrophages in adipose tissue have emerged as a critical pathogenic factor for diseases of modernity. The infiltration of macrophages induces a high circulation of pro-inflammatory cytokines in adipose tissue, such as tumor necrosis factor- $\alpha$ (TNF- $\alpha)$ that causes an inflammatory state (Harman-Boehm et al., 2007).
Studies show that the anti-inflammatory action of the Garcinia plants must undoubtedly be the presence of numerous phenolic compounds found in expressive concentrations in this genus (Liu et al., 2015; Ramachandran et al., 2014; Swami et al., 2014; Yoshimura et al., 2015).

In the study by Xie et al. (2015), the use of a mangosteen- based beverage in healthy adults showed a significant increase in anti- inflammatory capacity: the CRP level in the group treated with mangosteen decreased significantly from $2.9 \mathrm{mg} \mathrm{L}^{-1}$ on the first day to $1.6 \mathrm{mg} \mathrm{L}^{-1}$ on the 30 th day after consumption of the product.

In a similar study, a mixture of mangosteen juice $(G$. mangostana) administered to individuals between 30-75 years of age, body mass index (BMI) $\geq 30$ and $\leq 45$ $\mathrm{kg} / \mathrm{m}^{2}$ (obese), and high-sensitivity CRP (hs-CRP) of $\geq$ 3 , resulted in a decrease in these inflammatory markers after 8 weeks (Udani et al., 2009).

Supplementing of the G. cambogia extract with a highfat diet decreased significantly the levels of plasma leptin $(\mathrm{p}=0.031)$ and proinflammatory cytokine TNF- $\alpha$ $(\mathrm{p}=0.013)$ in experimental models (Sripradha and Magadi, 2015).

\section{Antioxidant activity}

Oxidative stress is closely linked to the diseases of modernity. Overproduction of reactive oxygen species (ROS) is considered to have a key role in hyperglycemia, dyslipidemia, and obesity (Liu et al., 2015). The antioxidant efficiency of bioactive compounds derived from plant depends on the structure and concentration. Use of aqueous extracts from $G$. indica fruit peels $\left(800 \mathrm{mg} \mathrm{kg}^{-1}\right)$ in the ethanol-induced hepatotoxicity of Wistar rats promoted significant hepatoprotective activity by restoring depleted levels of glutathione, glutathione peroxidase, catalase, superoxide dismutase and glutathione reductase, after 28 days (Panda et al., 2012).

In a study by Sripradha and Magadi (2015), treatment with G. cambogia ethanolic extract significantly increased the blood antioxidants, e.g., glutathione (GSH) content and activities of glutathione peroxidase (GPx) and catalase. There was also a decrease in plasma malondialdehyde levels along with a reduction in total 
oxidant status due to an increase in total antioxidant status in the plasma and liver of rats after supplementation.

There are several varieties of Garcinia species that have shown antioxidant activity in in vitro models. Infante (2013) identified in the pulp of $G$. brasiliensis, expressive antioxidant activity by the stable DPPH (2,2- diphenyl- 1- picryl- hydrazyl- hydrate)

free- radical, micellar model system linoleic acid- $\beta$ carotene and ORAC (oxygen radical absorbance capacity) assay. The aqueous and boiled kokam extract (G. indica) used in cooking and home remedies, in addition to the commercial kokam syrup, had significant antioxidant effects by ORAC method (Mishra et al., 2006).

The antioxidant activity of the $G$. atroviridis unripe fruits (1.63 mmol $\mathrm{l}^{-1}$ ), measured by FRAP (ferric reducing antioxidant power) assay, showed a significantly higher level compared to matured fruits (1.47 $\mathrm{mmol} \mathrm{l}^{-1}$ ) (Nursakinah et al., 2012).

The pulp of $G$. humilis, known in Brazil as $G$. achachairu, was characterized by the highest content of phenolic compound and antioxidant activity in the ABTS [(2,2'-azinobis-(3-etilbenzotiazolin-6-sulphonic) acid], DPPH and FRAP assays (Virgolin, 2015).

The extracts of $G$. lanceifolia and $G$. xanthochymus pericarp, collected from the homestead garden, exhibited high potential for free-radical scavenging by the DPPH and ABTS models (Gogoi et al., 2015). The fruit-peel of Garcinia brasiliensis offered high antioxidant activity by the DPPH method, as demonstrated by Naves (2014).

\section{Protection against cancer}

Many extracts of medicinal plants and their compounds represent an alternative to conventional cancer therapy. A considerable number of studies on the antitumor activities of Garcinia species have been reported, and their activities have often attributed to the presence of depsidones, triterpenes, benzophenones and xanthones (Mackeen et al., 2000; Xia et al., 2015). Among them, mangosteen fruit extracts, as well as xanthones extracted from its pericarp, cause an antitumor effect in various types of cancer (Mohamed et al., 2017; OvalleMagallanes et al., 2017).
In vitro studies involving chloroform extracts from the G. morella pulp showed anti-proliferative action (dose and time-dependent) on breast cancer cells (MCF7, MDAMB231 e SKBR3), with garcinol being the main bioactive component found in this fruit (Choudhury et al., 2018). Bagattoli et al. (2016) observed that the methanolic extract of $G$. achachairu inhibited the growth of tumor cells (B16F10 - murine melanoma) in in vitro analysis.

The extract of $G$. opaca fruit presented a cytotoxic effect on three human tumor cell lines, representing breast, lung and prostate tumors, with the extract considered to have a strong and selective activity (Jabit et al., 2009). Antiproliferative activities were also observed in ethanolic extract and the hexane and chloroform fractions of fruits of $G$. gardneriana (Demenciano et al., 2020).

Xanthochymol and isoxanthochymol were isolated from $G$. xanthochymus, G. mannii, G. stauditi, $G$. subeilliptica and $G$. pyrifera, which exhibited significant growth suppression in the human leukemia cell line (Bheemaiah and Kushalappa, 2019).

The fruit peel and the fresh extract of $G$. dulcis have been shown to be a protective agent for liver damages (hepatoprotective activity) in experimental models and a potential cancer chemotherapeutic agent against liver cancer cells in vitro, respectively (Abu Bakar et al., 2015; Gogoi et al., 2017).

\section{Conclusions}

Scientific literature has shown that the fruit of Garcinia species can be used in the prevention of cardiovascular disorders, cancer and diabetes mellitus, among other diseases associated with oxidative stress, in addition to controlling body weight and its damage to health. These fruits have pharmacologically active constituents, but some are commercially exploited as a fruit crop or for medicinal purposes. Further research must be carried out to assess the mechanism of action of bioactive compounds with beneficial effects for the population.

\section{Conflict of interest statement}

Authors declare that they have no conflict of interest. 


\section{References}

Abu Bakar, M.F., Ahmad, N.E., Suleiman, M., Rahmat, A., Isha, A., 2015. Garcinia dulcis fruit extract induced cytotoxicity and apoptosis in hepG2 liver cancer cell line. Biomed. Res. Int., 2015: 1-10.

Abuzaid, A.S., Sukandar, E.Y., Kurniati, N.F., Ketut Adnyana, I., 2017. Antihyperlidemic effects of mangosteen (Garcinia mangostana L.) pericarp ethanolic extract in high-carbohydrate Wistar rats. J. Nat. Remedies, 17: 165-173.

Akshay Kumar, S. V., Nanda, S.K., Bharathy, N., Ravichandran, K., Dinakaran, A., Ray, L., 2017. Evaluation of vitamin D status and its correlation with glycated haemoglobin in type 2 diabetes mellitus. Biomed. Res., 28: 66-70.

Al-Mansoub, M.A., Asmawi, M.Z., Murugaiyah, V., 2014. Effect of extraction solvents and plant parts used on the antihyperlipidemic and antioxidant effects of Garcinia atroviridis: A comparative study. J. Sci. Food Agric., 94:1552-1558.

Ali, M.Y., Paul, S., Tanvir, E.M., Hossen, M.S., Rumpa, N.-E.N., Saha, M., Bhoumik, N.C., Aminul Islam, M., Hossain, M.S., Alam, N., Gan, S.H., Khalil, M.I., 2017. Antihyperglycemic, antidiabetic, and antioxidant effects of Garcinia pedunculata in rats. Evidence-Based Complement. Altern. Med., 2017: 1-15.

Amin, K.A., Kamel, H.H., Abd Eltawab, M.A., 2011. Protective effect of Garcinia against renal oxidative stress and biomarkers induced by high fat and sucrose diet. Lipids Health Dis., 10: 1-13.

Amran, A.A., Zaiton, Z., Faizah, O., Morat, P., 2009. Effects of Garcinia atroviridis on serum profiles and atherosclerotic lesions in the aorta of guinea pigs fed a high cholesterol diet. Singapore Med. J., 50: 295-299.

Bagattoli, P.C.D., Cipriani, D., Mariano, L.N.B., Correa, M., Wagner, T., Noldin, V., Filho, Vc., Niero, R., 2016. Phytochemical, antioxidant and anticancer activities of extracts of seven fruits found in the Southern Brazilian flora. Indian J. Pharm. Sci., 78: 34-40.

Bheemaiah, M.M.; Kushalappa, B. A. 2019. Estimation and comparison of amount of organic acids from dried leaves of Garcinia cambogia, Garcinia indica, Garcinia xanthochymus, and Garcinia morella by high-performance liquid chromatography. Phcog Res.,11: 86-91.
Calvo, M.I., Cavero, R.Y., 2014. Medicinal plants used for cardiovascular diseases in Navarra and their validation from Official sources. $\mathrm{J}$. Ethnopharmacol., 157: 268-273.

Choudhury, B., Kandimalla, R., Elancheran, R., Bharali, R., Kotoky, J., 2018. Garcinia morella fruit, a promising source of antioxidant and antiinflammatory agents induces breast cancer cell death via triggering apoptotic pathway. Biomed. Pharmacother. 103, 562-573.

Chuah, L.O., Ho, W.Y., Beh, B.K., Yeap, S.K., 2013. Updates on Antiobesity Effect of Garcinia Origin (-)-HCA. Evidence-Based Complement. Altern. Med., 2013:1-17.

Demenciano, S.d.C., Silva, M.C.B.Le, Alexandrino, C.A.F., Kato Junior, W.H., Figueiredo, P.d.O., Garcez, W.S., Campos, R.P., Guimarães, R.d.C.A., Sarmento, U.C., Bogo, D., 2020. Antiproliferative activity and antioxidant potential of extracts of Garcinia gardneriana. Molecules, 25, 3201.

Espirito Santo, B.L.S.D., Santana, L.F., Kato Junior, W.H., de Araújo, F.d.O., Bogo, D., Freitas, K.D.C., Guimarães, R.d.C.A., Hiane, P.A., Pott, A., Filiú, W.F.d.O., Arakaki Asato, M., Figueiredo, P.d.O., Bastos, P.R.H.d.O., 2020. Medicinal potential of Garcinia species and their compounds. Molecules, 25: 4513.

Farahna, M., Seke Etet, P.F., Osman, S.Y., Yurt, K.K., Amir, N., Vecchio, L., Aydin, I., Aldebasi, Y.H., Sheikh, A., Chijuka, J.C., Kaplan, S., Adem, A., 2017. Garcinia kola aqueous suspension prevents cerebellar neurodegeneration in long-term diabetic rat - a type 1 diabetes mellitus model. J. Ethnopharmacol., 195: 159-165.

Farinazzi-Machado, F.M.V., 2017. Can the consumption of seeds, leaves and fruit peels avoid the risk factors for cardiovascular disorders? Int. J. Nutrology, 10: 37-45.

Farinazzi-Machado, F.M.V., Barbalho, S.M., Guiguer, E.L., Marinelli, P.S., Ishida, I.B., Lopes Vieites, R., Groppo, M., 2016. Phytochemical screening of the fruit of Garcinia cochinchinensis Choisy. Int. J. Curr. Res. Biosci. Plant Biol., 3: 81-89.

Fassina, P., Adami, F.S., Zani, V.T., Machado, I.C.K., Garavaglia, J., Grave, M.T.Q., Ramos, R., Bosco, S.M.D., 2015. The effect of Garcinia cambogia as coadjuvant in the weight loss process. Nutr. Hosp., 32: 2400-2408.

Gogoi, N., Gogoi, A., Neog, B., 2015. Free radical scavenging activities of Garcinia xanthochymus 
Hook. F. and Garcinia lanceaefolia Roxb. using various in vitro assay models. Asian J. Pharm. Clin. Res., 8: 138-141.

Gogoi, N., Gogoi, A., Neog, B., Baruah, D., Singh, K., 2017. Evaluation of antioxidant and hepatoprotective activity of fruit rind extract of Garcinia dulcis (Roxburgh) Kurz. Pharmacogn. Res., 9: 266-272.

González-Chávez, A., Elizondo-Argueta, S., GutiérrezReyes, G., León-Pedroza, J.I., 2011. Pathophysiological implications between chronic inflammation and the development of diabetes and obesity. Cir. Cir., 79: 209-216.

Guedes, R.F., 2016. Análise do perfil lipídico e dos fatores de risco associados a doenças cardiovasculares em acadêmicos da área da saúde de Juiz de Fora. HU Rev., 42: 159-164.

Guerrero-García, C., Rubio-Guerra, F., 2018. Combination therapy in the treatment of hypertension. Drugs Context, 7: 1-9.

International Diabetes Federation (IDF), 2015). Diabetes Atlas - 7th Edition. DiabetesAtlas http://www. diabetesatlas.org/

Hargunani, P., Sharma, S., Pai, A., Patil, B., Jain, A., 2020. Garcinia cambogia: an ancient fruit rind with recently discovered therapeutic activity. J. Med. Pharm. All. Sci., 9-I: 2391-2397.

Hassan, M. A., Basar, N., Ahmad, F., 2017. Chemical constituents and antioxidant activity of Garcinia parvifolia Miq. stem bark. eProc. Chem., 1: 67-70.

Harman-Boehm, I., Blüher, M., Redel, H., SionVardy, N., Ovadia, S., Avinoach, E., Shai, I., Klöting, N., Stumvoll, M., Bashan, N., Rudich, A., 2007. Macrophage infiltration into omental versus subcutaneous fat across different populations: effect of regional adiposity and the comorbidities of obesity. J. Clin. Endocrinol. Metab., 92 : 2240-2247.

Infante, J., 2013. Composição fenólica e atividade antioxidante de polpa, casca, semente e folha de espécies frutíferas nativas do Brasil. Universidade de São Paulo.

Jabit, M.L., Wahyuni, F.S., Khalid, R., Israf, D.A., Shaari, K., Lajis, N.H., Stanslas, J., 2009. Cytotoxic and nitric oxide inhibitory activities of methanol extracts of Garcinia species. Pharm. Biol., 47: 1019-1026.

Kim, Y.-J., Choi, M.-S., Park, Y.B., Kim, S.R., Lee, M.K., Jung, U.J., 2013. Garcinia cambogia attenuates diet-induced adiposity but exacerbates hepatic collagen accumulation and inflammation. World J. Gastroenterol., 19: 4689-4701.

Kirana, H., Srinivasan, B.P., 2010. Aqueous extract of Garcinia indica Choisy restores glutathione in type 2 diabetic rats. J. Young Pharm., 2: 265-268.

Lee, D., Kim, Y.-M., Jung, K., Chin, Y.-W., Kang, K., 2018. Alpha-mangostin improves insulin secretion and protects INS-1 cells from streptozotocininduced damage. Int. J. Mol. Sci., 19: 1-13.

Liu, B., Zhang, X., Bussmann, R.W., Hart, R.H., Li, P., Bai, Y., Long, C., 2016. Garcinia in Southern China: Ethnobotany, management, and niche modeling. Econ. Bot., 70: 416-430.

Liu, Q.-Y., Wang, Y.-T., Lin, L.-G., 2015. New insights into the anti-obesity activity of xanthones from Garcinia mangostana. Food Funct., 6: 383-393.

Mackeen, M.., Ali, A.., Lajis, N.., Kawazu, K., Hassan, Z., Amran, M., Habsah, M., Mooi, L.., Mohamed, S.., 2000. Antimicrobial, antioxidant, antitumourpromoting and cytotoxic activities of different plant part extracts of Garcinia atroviridis Griff. ex T. Anders. J. Ethnopharmacol., 72: 395-402.

Marques, E.S., Leite, T.H., Azeredo, C.M., Cunha, D.B., Verly Júnior, E., 2018. Effective strategies for prevention, control, and treatment of obesity in primary health care setting for adolescents, adults, and elderly people. Medicine (Baltimore), 97: $1-4$.

Mishra, A., Bapat, M.M., Tilak, J.C., Devasagayam, T.P., 2006. Antioxidant activity of Garcinia indica (kokam) and its syrup. Curr. Sci., 91: 9093.

Mohamed, G.A., Al-Abd, A.M., El-halawany, A.M., Abdallah, H.M., Ibrahim, S.R.M., 2017. New xanthones and cytotoxic constituents from Garcinia mangostana fruit hulls against human hepatocellular, breast, and colorectal cancer cell lines. J. Ethnopharmacol., 198: 302-312.

Mohammedi, K., Patente, T.A., Bellili-Muñoz, N., Driss, F., Le Nagard, H., Fumeron, F., Roussel, R., Hadjadj, S., Corrêa-Giannella, M.L., Marre, M., Velho, G., 2016. Glutathione peroxidase-1 gene (GPX1) variants, oxidative stress and risk of kidney complications in people with type 1 diabetes. Metabolism, 65: 12-19.

Moreira, M.E. de C., Natal, D.I.G., Toledo, R.C.L., Ramirez, N.M., Ribeiro, S.M.R., Benjamin, L. dos A., de Oliveira, L.L., Rodrigues, D.A., Antônio, J.D., Veloso, M.P., Dos Santos, M.H., Martino, H.S.D., 2017. Bacupari peel extracts (Garcinia 
brasiliensis) reduce high-fat diet-induced obesity in rats. J. Funct. Foods, 29: 143-153.

Naves, V. de M.L., 2014. Caracterização química e biológica in vitro de extratos de Garcinia brasiliensis e avaliação do seu perfil de permeação cutânea em formulações dermatológicas. Universidade Federal de Alfenas.

Ness, A., 2004. Diet, Nutrition and the prevention of chronic diseases. WHO technical report series 916. Report of a Joint WHO/FSA Expert Consultation. Int. J. Epidemiol., 33: 914-915.

Nordestgaard, B.G., Varbo, A., 2014. Triglycerides and cardiovascular disease. Lancet, 384: 626-635.

Nursakinah, I., Zulkhairi, H.A., Norhafizah, M., Hasnah, B., Zamree Md, S., Farrah Shafeera, I., Razif, D., Hamzah Fansuri, H., 2012. Nutritional content and in vitro antioxidant potential of Garcinia atroviridis (asam gelugor) leaves and fruits. Malays. J. Nutr., 18: 363-371.

Oluyemi, K.A., Omotuyi, I.O., Jimoh, O.R., Adesanya, O.A., Saalu, C.L., Josiah, S.J., 2007. Erythropoietic and anti-obesity effects of Garcinia cambogia (bitter kola) in Wistar rats. Biotechnol. Appl. Biochem., 46: 69-72.

Ovalle-Magallanes, B., Eugenio-Pérez, D., PedrazaChaverri, J., 2017. Medicinal properties of mangosteen (Garcinia mangostana L.): A comprehensive update. Food Chem. Toxicol., 109: 102-122.

Oyagbemi, A., Omobowale, T., Adedapo, A., Yakubu, M., 2016. Kolaviron, biflavonoid complex from the seed of Garcinia kola attenuated angiotensin II- and lypopolysaccharide-induced vascular smooth muscle cell proliferation and nitric oxide production. Pharmacogn. Res. 8, S50-S55.

Panda, V., Ashar, H., Srinath, S., 2012. Antioxidant and hepatoprotective effect of Garcinia indica fruit rind in ethanolinduced hepatic damage in rodents. Interdiscip. Toxicol., 5: 207-213.

Ramachandran, H.D., Fayaz, P., Kusum, R., 2014. Plant profile, phytochemistry and pharmacology of Garcinia indica: A review. Int. J. Pharm. Sci. Rev. Res., 27 : 361-366.

Sarma, R., Kumari, S., Elancheran, R., Deori, M., Devi, R., 2016. Polyphenol rich extract of Garcinia pedunculata fruit attenuates the hyperlipidemiai by high fat diet. Front. Pharmacol., 7: 1-11.

Seidell, J.C., Halberstadt, J., 2015. The Global Burden of Obesity and the Challenges of Prevention. Ann. Nutr. Metab., 66: 7-12.
Semwal, R.B., Semwal, D.K., Vermaak, I., Viljoen, A., 2015. A comprehensive scientific overview of Garcinia cambogia. Fitoterapia, 102: 134-148.

Sripradha, R., Magadi, S.G., 2015. Efficacy of Garcinia cambogia on body weight, inflammation and glucose tolerance in high fat fed male Wistar rats. J. Clin. Diagn. Res., 9: BF01-BF04.

Sripradha, R., Sridhar, M.G., Maithilikarpagaselvi, N., 2016. Antihyperlipidemic and antioxidant activities of the ethanolic extract of Garcinia cambogia on high fat diet-fed rats. J. Complement. Integr. Med., 13: 9-16.

Swami, S.B., Thakor, N.J., Patil, S.C., 2014. Kokum (Garcinia indica) and its many functional components as related to the human health: A review. J. Food Res. Technol., 2: 130-142.

Taher, M., Tg Zakaria, T.M.F.S., Susanti, D., Zakaria, Z.A., 2016. Hypoglycaemic activity of ethanolic extract of Garcinia mangostana Linn. in normoglycaemic and streptozotocin-induced diabetic rats. BMC Complement. Altern. Med., 16: $1-12$.

Udani, J.K., Singh, B.B., Barrett, M.L., Singh, V.J., 2009. Evaluation of mangosteen juice blend on biomarkers of inflammation in obese subjects: a pilot, dose finding study. Nutr. J., 8: 1-7.

Vasques, C.A.R., Schneider, R., Klein-Júnior, L.C., Falavigna, A., Piazza, I., Rossetto, S., 2014. Hypolipemic effect of Garcinia cambogia in obese women. Phyther. Res., 28: 887-891.

Veigas, L., Pereira, P.C., Vicente, F., Mesquita, M.F., 2012. Overweight, obesity and abdominal adiposity effects in inflammatory proteins: C-reactive protein and fibrinogen. J. Med. Sci., 12: 70-77.

Virgolin, L.B., 2015. Caracterização físico-química de polpas de frutas do bioma Amazônia. Universidade Estadual Paulista.

Watanabe, M., Gangitano, E., Francomano, D., Addessi, E., Toscano, R., Costantini, D., Tuccinardi, D., Mariani, S., Basciani, S., Spera, G., Gnessi, L., Lubrano, C., 2018. Mangosteen extract shows a potent insulin sensitizing effect in obese female patients: A prospective randomized controlled pilot study. Nutrients, 10: 1-10.

Xia, Z., Zhang, H., Xu, D., Lao, Y., Fu, W., Tan, H., Cao, P., Yang, L., Xu, H., 2015. Xanthones from the leaves of Garcinia cowa induce cell cycle arrest, apoptosis, and autophagy in cancer cells. Molecules, 20: 11387-11399.

Xie, Z., Sintara, M., Chang, T., Ou, B., 2015. Daily 
consumption of a mangosteen- based drink improves in vivo antioxidant and anti- inflammatory biomarkers in healthy adults: a randomized, double-blind, placebo- controlled clinical trial. Food Sci. Nutr., 3: 342-348.

Yazew, T; Daba, A. Health Benefits of Fruit and Vegetables Consumption: Preventive Implications for Non-communicable Diseases in Ethiopia. 2020. Adv. Tech. Biol. Med., 8: 1-5.

Yoshimura, M., Ninomiya, K., Tagashira, Y., Maejima, K., Yoshida, T., Amakura, Y., 2015. Polyphenolic constituents of the pericarp of mangosteen (Garcinia mangostana L.). J. Agric. Food Chem., 63: 7670-7674.

\section{How to cite this article:}

Farinazzi-Machado, F. M. V., Silva, A. R., 2021. Garcinia fruit: in the forests and domestic orchards, the prevention of diseases of modernity. Int. J. Curr. Res. Biosci. Plant Biol., 8(5): 4-13.

doi: https://doi.org/10.20546/ijcrbp.2021.805.002 